\title{
Synthesis and Evaluation of Olivine Material Coated with Carbon
}

\author{
Masakazu Togo ${ }^{1, a}$ and Atsushi Nakahira ${ }^{1}$ \\ ${ }^{1}$ Department of Materials Science, Osaka Prefecture University, 1-1 Gakuen-cho, Nakaku, Sakai, Osaka, JAPAN
}

\begin{abstract}
Lithium iron phosphate, $\mathrm{LiFePO}_{4}$, was synthesized by hydrothermal process and subsequently coated with carbon by the thermal decomposition of acetylene gas. The products were characterized by XRD, SEM, and TG-DTA. As-synthesized $\mathrm{LiFePO}_{4}$ was submicron sized plate-like particle. After heating at various temperature in nitrogen atmosphere, the particle size and the crystalline sizes were grown with increasing the heating temperature. Above $700^{\circ} \mathrm{C}$, the grain growth was remarkably. Carbon coating temperature was set at $500-600^{\circ} \mathrm{C}$ because of fine particle and good crystallinity. As a carbon raw material, acetylene gas was flowing to the as-synthesized $\mathrm{LiFePO}_{4}$ in nitrogen atmosphere, and the $\mathrm{LiFePO}_{4} / \mathrm{C}$ composite was obtained. TG curves showed weight loss above $500^{\circ} \mathrm{C}$, which was thought to be associated with carbon layer composition.
\end{abstract}

\section{Introduction}

$\mathrm{LiCoO}_{2}$ has been used as a cathode material for lithium ion batteries. Usage of cobalt prohibits to reduce the material costs because of scarcity. The amount of needed lithium ion battery increases significantly for the application of EV and energy storage system. Then, the development of Co-free cathode material is quietly important. Lithium iron phosphate, $\mathrm{LiFePO}_{4}$, is the material, in which iron having high number of Clark is rich in resources, and is inexpensive. Padhi et al. reported that polyanion material like as $\mathrm{LiFePO}_{4}$ and $\mathrm{Li}_{2} \mathrm{FeSiO}_{4}$, showed the charge-discharge property as cathode for LIB. [1] $\mathrm{LiFePO}_{4}$ shows $3.5 \mathrm{~V}$ v.s. Li of reversible potential and $170 \mathrm{mAhg}^{-1}$ of theoretical capacity. These values are the energy density comparable to $\mathrm{LiCoO}_{2}$.

$\mathrm{LiFePO}_{4}$ has orthorhombic crystal olivine type structure. The crystal structure of $\mathrm{LiFePO}_{4}$ is showed in Figure 1. $\mathrm{FeO}_{6}$ octahedra and $\mathrm{PO}_{4}$ tetrahedra have the structure that a ridge shared one side, and $\mathrm{Li}$ arranges it in a b-axis. $\mathrm{PO}_{4}$ tetrahedra is strongly connected by covalent bond, and it restrains the oxygen decomposition. The structure stability of produce for $\mathrm{LiFePO}_{4}$ the safety. On the other hand, ionic conduction for $\mathrm{LiFePO}_{4}$ is difficult because a $\mathrm{Li}$ ion in structure is localized electronically. The discharge reaction of $\mathrm{LiFePO}_{4}$ is showed in the following equation.

$$
\mathrm{LiFePO}_{4} \rightarrow \mathrm{Li}_{1-x} \mathrm{FePO}_{4}+x \mathrm{Li}^{+}+x e^{-}
$$

In the discharge reaction, $\mathrm{FePO}_{4}$ phase is formed by deintercalation of the lithium ion. With the biphase reaction of $\mathrm{LiFePO}_{4}$ and $\mathrm{FePO}_{4}$, equilibrium potential is seen in around $3.5 \mathrm{~V}$. Both structure is similar, and cycle capability with charge-discharge reaction is good because the symmetricalness of both does not change. As a model

\footnotetext{
a Corresponding author: st110029@edu.osakafu-u.ac.jp
}

of these reaction, domino-cascade model is proposed. [2] In a border between $\mathrm{LiFePO}_{4}$ and $\mathrm{FePO}_{4}$ with the disorder of the atom placement, electronic conductivity is relatively high, and it is thought that $\mathrm{Li}^{+}$is deintercalated from there. The conductivity of $10^{-8}-10^{-9} \mathrm{~S} / \mathrm{cm}$ for $\mathrm{LiFePO}_{4}$, however, is very lower than that of $10^{-2} \mathrm{~S} / \mathrm{cm}$ for $\mathrm{LiCoO}_{2}$. [3] Therefore, the problem for commercial use is this low conductivity, and the improvement of conductivity can lead to the good rate capability. In order to improve the conductivity, many researchers have been tried. First, focused on the material composition, it reported that the multi cation doped $\mathrm{LiFePO}_{4}$ showed the good rate capability. It was because that the doped cations, such as $\mathrm{Mg}^{2+}, \mathrm{Al}^{3+}, \mathrm{Zr}^{4+}, \mathrm{Nb}^{5+}$ and $\mathrm{W}^{6+}$, reduce the volumetric resistance. [4] On the other hand, the microstructure for the electrode materials is also important. If the electrode material makes a fine particle, its reactivity increases due to the improvement of the supecific surface area. In addition, the diffusion length of the ion is shortened by microparticulation, and this is quietly advantageous. There were the reports focused on the morphology with high performance. [5] In order to obtain the finer particle, a various synthesis method has been examined. A. Yamada reported that the optimization of solid state reaction conditions produced a fine particle, and it showed a good performance. [6] However, the diffusion necessary for a complete reaction needs the condition at high temperature for long-time. As the synthesis method at lower temperature, many methods such as hydrothermal method [7], sol-gel method [8, 9], and splay pyrolysis method [10] are reported. In this study, using the hydrothermal process, the synthesis of $\mathrm{LiFePO}_{4}$ composed of a fine particle was attempted.

In order to cope with high rate charge-discharge reaction, $\mathrm{LiFePO}_{4}$ needs not only the microparticulation but also 
the composition with conductive assistant. Coating on $\mathrm{LiFePO}_{4}$ particle surfaces is suitable to make a little conductive assistant in the composition methods. The conduction layer has two kinds of an electronic conduction and the ionic conduction. B. Kang reported the ionic conduction layer. [11] The amorphous $\mathrm{Li}_{4} \mathrm{P}_{2} \mathrm{O}_{7}$ phase as the ionic conduction layer was precipitated by making non-stoichiometric composition. This amorphous phase prohibit the grain growth, and finer particle would be obtained. As the result, the obtained active material showed good property with $130 \mathrm{mAh} / \mathrm{g}$ of the discharging capacity at high rate. On the contrary, as the electronic conduction layer, carbon coating has been examined. There are various kinds of raw carbon material and that composition methods. Then, the $\mathrm{LiFePO}_{4} / \mathrm{C}$ composite produced by heating the mixture of the active material and ractose in inert atmosphere [12], and depositing carbon from heat decomposition of propylene gas. [13] The products by wet method are easy to be affected to the crystalinity and the grain growth among heating process. In this research, $\mathrm{LiFePO}_{4}$ was synthesized by hydrothermal method, and the products was coated with carbon by the thermal decomposition of acetylene gas. The influence of carbon coating process to $\mathrm{LiFePO}_{4}$ was examined.

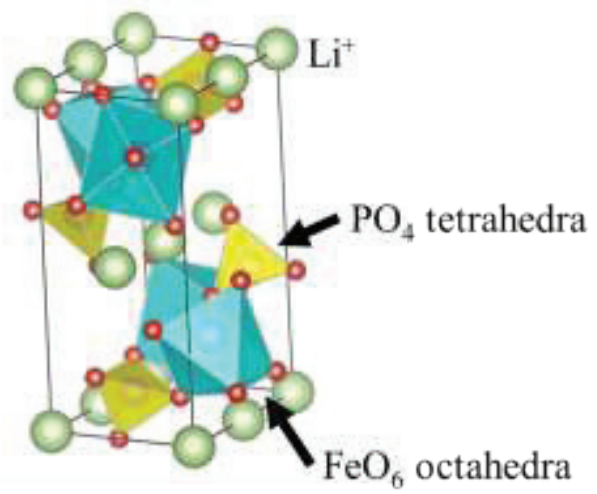

Figure 1. Olivine-type structure of $\mathrm{LiFePO}_{4}$.

\section{Experimental procedure}

\subsection{Synthesis}

\subsubsection{Synthesis of $\mathrm{LiFePO}_{4}$ by hydrothermal process}

LiOH. $\mathrm{H}_{2} \mathrm{O}, \quad\left(\mathrm{NH}_{4}\right)_{2} \mathrm{HPO}_{4}$ and $\mathrm{FeSO}_{4} \cdot 7 \mathrm{H}_{2} \mathrm{O}$ (Wako Chemical) were used as starting materials. Each starting materials were weighted to become a molar ratio of Li: P: $\mathrm{Fe}=2: 1: 1$. After measurement, they were put into distilled water in Teflon vessel and vigorously mixed for a few minutes. Teflon vessel with mixed solution was encapsulated into autoclave and was hydrothermally treated at $200^{\circ} \mathrm{C}$ for 24 hours. Obtained slurry was filtrated and then dried at $50^{\circ} \mathrm{C}$ for overnight.

\subsubsection{Heat treatment of $\mathrm{LiFePO}_{4}$}

$\mathrm{LiFePO}_{4}$ synthesized by hydrothermal treatment was heated in nitrogen atmosphere. $0.5 \mathrm{~g}$ of $\mathrm{LiFePO}_{4}$ was measured, and it was put in carbon crucible. Carbon crucible was moved in a furnace. After the furnace was evacuated slowly, nitrogen gas was carried out with flow $5 \mathrm{~L} / \mathrm{min}$ for $30 \mathrm{~min}$. Then, the flow quantity of nitrogen gas was controlled $0.2 \mathrm{~L} / \mathrm{min}$. The furnace was raised up to target temperature $\left(\mathrm{T}=400-800^{\circ} \mathrm{C}\right)$ with heat rate of $4^{\circ} \mathrm{C} / \mathrm{min}$ and kept it for 2 hours.

\subsection{3 $\mathrm{LiFePO}_{4} / \mathrm{C}$ composites by thermal decomposition}

Rotary kiln (Takasago Industry Co., Ltd.) showed in Figure 2 was used for the manufacture of the $\mathrm{LiFePO}_{4} / \mathrm{C}$ composite. $5 \mathrm{~g}$ of $\mathrm{LiFePO}_{4}$ was measured, and it was put in carbon capsule for product. Capsule was rolled at the rate of $1 \mathrm{rpm}$. In order to reduce the oxygen concentration in the capsule, $\mathrm{N}_{2}$ gas was carried out with flow of $5 \mathrm{~L} / \mathrm{min}$ for $15 \mathrm{~min}$. Then, $0.2 \mathrm{~L} / \mathrm{min}$ of acetylene gas was flowing to the capsule through a pipe of the alumina. The capsule was heated externally at $550^{\circ} \mathrm{C}$ and $600^{\circ} \mathrm{C}$ for 1 hour, respectively.

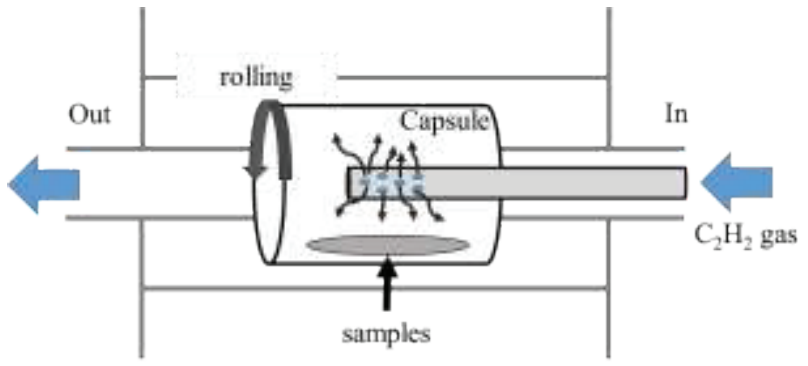

Figure 2. Schematic rotary kiln

\subsection{Evaluation}

The crystal phase of samples was indexed by XRD (UltimaIV, Rigaku Co., Japan). Scans were performed at $2 \theta=10-40^{\circ}$ with scan rate of $4 \%$ min using $\mathrm{Cu}-\mathrm{K} \alpha$ radiation. In order to estimate the lattice parameter of samples, internal reference method was used using pure Si powder. The morphology was observed by FE-SEM (s-4500, Hitachi, Japan) with applied voltage of $15 \mathrm{kV}$. Thermal gravimetric analysis was carried out under air atmosphere between room temperature and $700^{\circ} \mathrm{C}$, and the flow rate of the synthetic air was $2 \mathrm{~mL} / \mathrm{min}$.

\section{Results and discussions}

\subsection{Synthesis of $\mathrm{LiFePO}_{4}$ by hydrothermal process}

$\mathrm{LiFePO}_{4}$ was synthesized by hydrothermal process at $200^{\circ} \mathrm{C}$ for $24 \mathrm{~h}$. XRD patterns of the products were showed in Figure 3. The diffraction peaks attributed to olivine-type structure (JCPDS\#83-2092) were shown, and the other peaks considered the secondary phase like $\mathrm{Li}_{3} \mathrm{PO}_{4}$ and $\mathrm{Fe}_{2} \mathrm{P}$ were not confirmed. So, the products by hydrothermal method was identified as olivine-type 
structure. The lattice parameter estimated by inter reference method was $a=10.336 \AA, b=6.002 \AA, c=4.695 \AA$. This result was good agreement with JCPDS value $(a=10.3340 \AA, b=6.0100 \AA, c=4.6930 \AA)$. In the case of hydrothermal process, it was reported that the lattice parameter of $\mathrm{LiFePO}_{4}$ depended on the reaction condition, especially reaction temperature. [14] At higher reaction temperatures, the unit cell volume was closer to the value of $290.5 \AA^{3}$. The unit cell volume of the products by hydrothermal process was $291.3 \AA^{3}$. As this difference was thought to be case by the crystal purity, the products by hydrothermal process in this study would have the relatively high crystallinity. In addition, the crystalline from (311) plane was $35 \mathrm{~nm}$. Therefore, using of this assynthesized $\mathrm{LiFePO}_{4}$, the heat-treatments for $\mathrm{LiFePO}_{4}$ and the subsequent synthesis of $\mathrm{LiFePO}_{4} / \mathrm{C}$ composite was attempted.

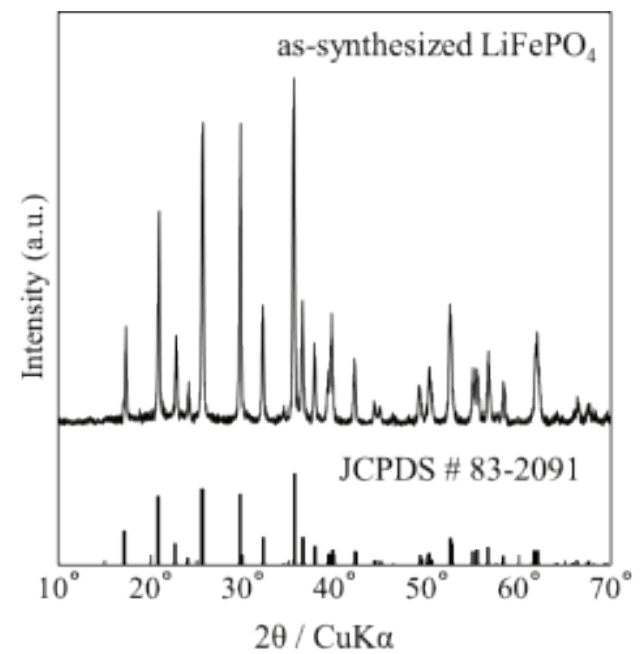

Figure 3 XRD patterns of the product synthesized by hydrothermal process.

\subsection{Heat treatments of $\mathrm{LiFePO}_{4}$}

The as-synthesized $\mathrm{LiFePO}_{4}$ was heated at $400-800^{\circ} \mathrm{C}$ in nitrogen atmosphere. Heating process is affected to the crystalline and the grain growth, so that is important role to influence the last products. The influence of heating process was examined. In Figure 4, the crystal phase of the products heated at various temperature in $\mathrm{N}_{2}$ atmosphere was identified by XRD analysis. After heating, no diffraction peaks of the secondary phases except the peaks attributed olivine-type phase was appeared. In addition, the peak intensity increased with the higher temperature. Therefore, it was thought that the decomposition of $\mathrm{LiFePO}_{4}$ or the phase transformation due to heating process was not occurred, after heattreatments, but the crystallinity was well done. Next, the crystalline sizes were estimated by Scherar equation with the following, and the result was plotting in Figure 5.

$$
D=K \lambda / \beta \cos \theta
$$

The peaks belonged to nine lattice plane, (200), (101), (210), (201), (020), (301), (311), (121) and (410), were used for analysis. In (311) plane, the crystalline size was
$41 \mathrm{~nm}$ at $400^{\circ} \mathrm{C}$ larger than that of as-synthesized $\mathrm{LiFePO}_{4}$. The crystalline size tended to be increased linearly with heating temperature. At $800^{\circ} \mathrm{C}, 84 \mathrm{~nm}$ of the crystalline size was estimated. Similarly, the same tendency was seen with the other diffraction peaks. In addition, the remarkable difference was appeared in the range of $600^{\circ} \mathrm{C}$ to $700^{\circ} \mathrm{C}$.

In Figure 5, SEM images of the heated products was shown. The particle size of the as-synthesized $\mathrm{LiFePO}_{4}$ was about $0.5 \mu \mathrm{m}$ and the morphology was plate-like particle. Finer particles were also observed in a part. There was no effect of particle size on longer reaction time, so no growth particle was generated during heattreatments. Next, the size of samples at $400^{\circ} \mathrm{C}$ was about $0.5 \mu \mathrm{m}$ similar to no-heated samples and the shape became the round particle without finer particles. In addition, the particle size increased remarkably with heated temperature above $600^{\circ} \mathrm{C}$. At $800^{\circ} \mathrm{C}$, the coarse particle was observed, and the particle size was up to $1 \mu \mathrm{m}$. From these observation, it was thought that the grain growth occurred above $600^{\circ} \mathrm{C}$.

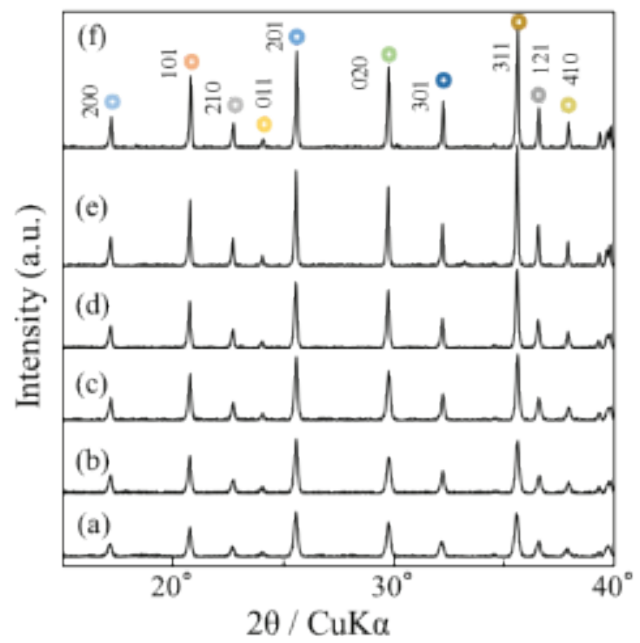

Figure 4 XRD patterns of the olivine products annealed in $\mathrm{N}_{2}$ atmosphere at $400^{\circ} \mathrm{C}, 500^{\circ} \mathrm{C}, 600^{\circ} \mathrm{C}, 700^{\circ} \mathrm{C}, 800^{\circ} \mathrm{C}$

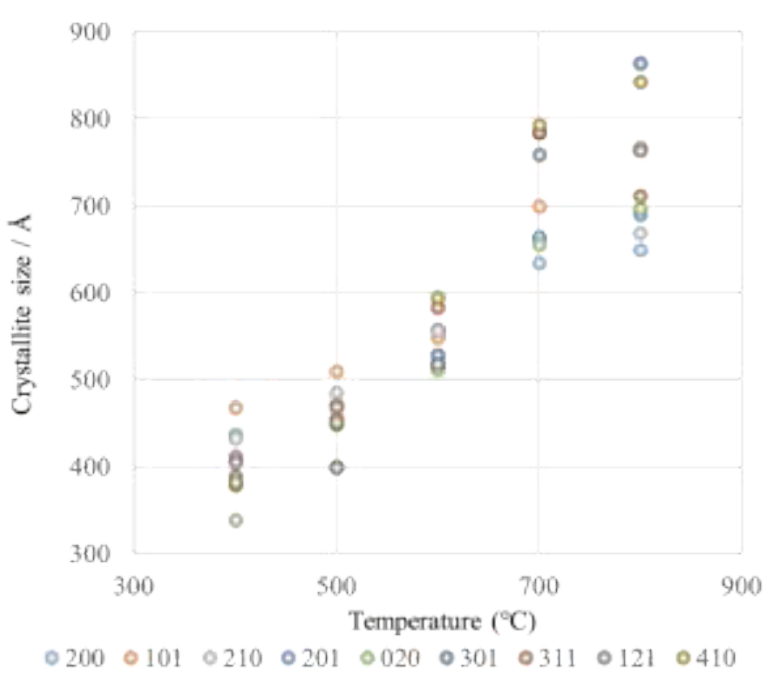

Figure 4 Crystalline sizes estimated by Scherar equation at each annealed temperature. 


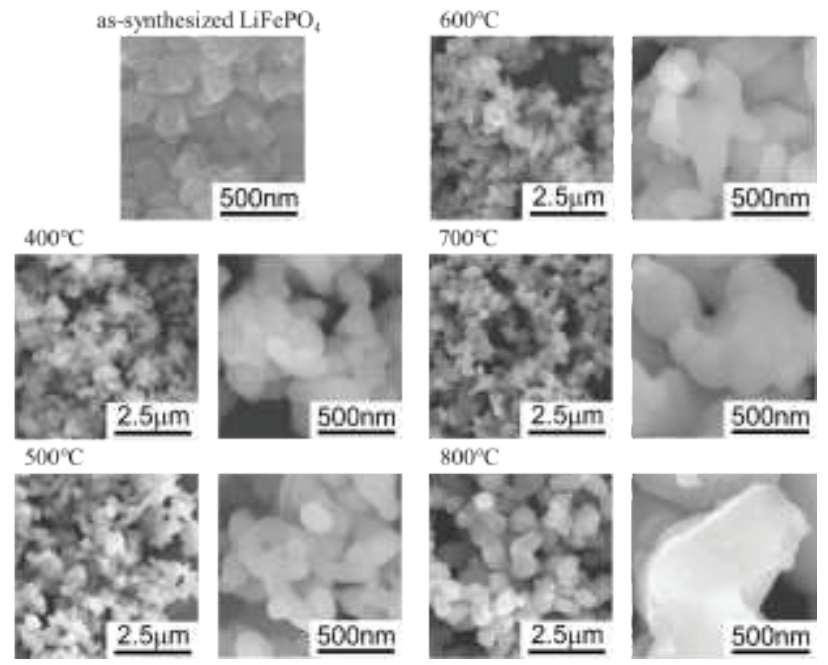

Figure 5 SEM images of the olivine products annealed in $\mathrm{N}_{2}$ atmosphere at $400^{\circ} \mathrm{C}, 500^{\circ} \mathrm{C}, 600^{\circ} \mathrm{C}, 700^{\circ} \mathrm{C}, 800^{\circ} \mathrm{C}$

As a result, heating process led to the improvement of the crystallinity. Below $600^{\circ} \mathrm{C}$, amorphous phase or amorphous layer on particle surface was crystalized and the grain growth was not remarkable. Above $600^{\circ} \mathrm{C}$, the grain growth was occurred, and it led to crystalline improvement.

\section{3 $\mathrm{LiFePO}_{4} / \mathrm{C}$ composites by thermal decomposition}

The $\mathrm{LiFePO}_{4} / \mathrm{C}$ composite was synthesized by the thermal decomposition of acetylene gas. With flowing of acetylene gas, the as-synthesized $\mathrm{LiFePO}_{4}$ was heated at various temperature for 1 hour. The reaction temperature was settled at $550^{\circ} \mathrm{C}$ and $600^{\circ} \mathrm{C}$ which the crystallinity was improved and no grain growth occurred. XRD patterns of the products thermal-decomposed at $550^{\circ} \mathrm{C}$ and $600^{\circ} \mathrm{C}$ with flow of acetylene gas were showed in Figure 6 . The diffraction peaks were attributed to olivinetype structure, and the secondary phase were not appeared. During this thermal decomposition, no oxidation was occurred for obtained olivine. SEM images were shown in Figure 7. The particle size was about $0.6 \mu \mathrm{m}$. At both $550^{\circ} \mathrm{C}$ and $600^{\circ} \mathrm{C}$, no grain growth during thermal decomposition was occurred remarkably. But, whereas the round particle was observed for samples at $550^{\circ} \mathrm{C}$, the square shape was appeared partially at $600^{\circ} \mathrm{C}$. The thermal decomposition of acetylene gas was exothermal reaction of $228 \mathrm{~kJ} / \mathrm{mol}$. The morphology change of samples that morphology of squared shapes was similar to that at higher reaction temperature was thought to be related with exothermal reaction.

Thermal stability characterization of the obtained $\mathrm{LiFePO}_{4} / \mathrm{C}$ composite was examined in air condition. TG-DTA curves were draw in Figure 8. In air, $\mathrm{LiFePO}_{4}$ was oxidized with following the reaction. [15]

$$
\mathrm{LiFePO}_{4}+1 / 4 \mathrm{O}_{2} \rightarrow 1 / 3 \mathrm{Li}_{3} \mathrm{Fe}_{2}\left(\mathrm{PO}_{4}\right)+1 / 6 \mathrm{Fe}_{2} \mathrm{O}_{3}
$$

Estimated total weight gain is $4.2 \%$. In case of the assynthesized $\mathrm{LiFePO}_{4}$, after initial weight loss associated to loss of water under $250^{\circ} \mathrm{C}$, TG curves showed weight gain of $2.8 \%$. From DTA curves, the exothermic peak was observed at around $300^{\circ} \mathrm{C}$, and the oxidation would be occurred. On the other hand, initial weight loss was not appeared for $\mathrm{LiFePO}_{4} / \mathrm{C}$ products. Then, weight gain associated to the oxidation started at around $300^{\circ} \mathrm{C}$ and weight loss started at around $500^{\circ} \mathrm{C}$. This weight loss was thought to be caused by the burning of carbon phase. Therefore, the $\mathrm{LiFePO}_{4} / \mathrm{C}$ composite were successfully synthesized. In addition, the oxidation starting temperature was different from the $\mathrm{LiFePO}_{4} / \mathrm{C}$ heated at $550^{\circ} \mathrm{C}$ in that heated at $600^{\circ} \mathrm{C}$. Thus, it was thought that the oxidation reaction was dependent on coated carbon layer on $\mathrm{LiFePO}_{4} / \mathrm{C}$ composites.

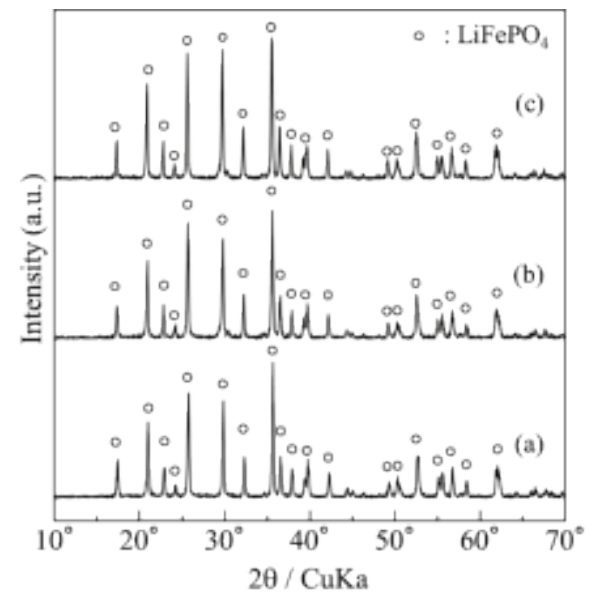

Figure $6 \mathrm{XRD}$ patterns of $\mathrm{LiFePO}_{4} / \mathrm{C}$ composite samples annealed in $\mathrm{N}_{2}$ atmosphere. (a) as-synthesized $\mathrm{LiFePO}_{4}$, (b) annealed at $550^{\circ} \mathrm{C}$ with flow of acetylene gas and (c) annealed at $600{ }^{\circ} \mathrm{C}$ with flow of acetylene gas.
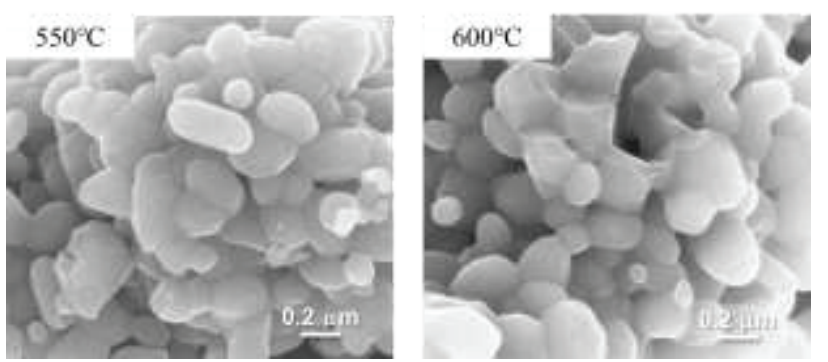

Figure 7 SEM images of $\mathrm{LiFePO}_{4} / \mathrm{C}$ composite samples annealed in $\mathrm{N}_{2}$ atmosphere at $550{ }^{\circ} \mathrm{C}, 600{ }^{\circ} \mathrm{C}$
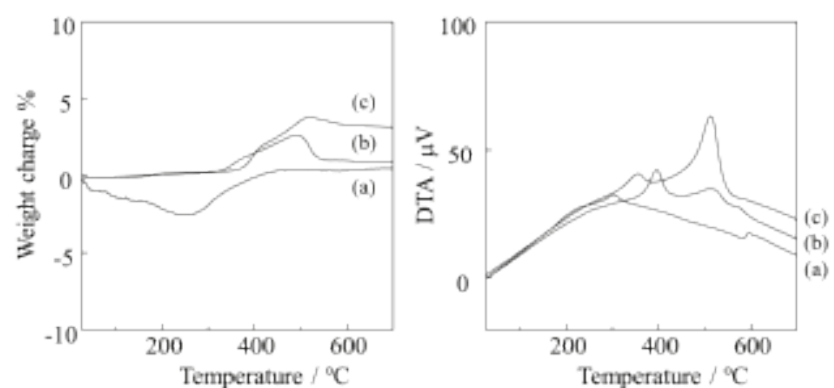

Figure 8 TG-DTA analysis of the $\mathrm{LiFePO}_{4} / \mathrm{C}$ composite samples: (a) as-synthesized $\mathrm{LiFePO}_{4}$, (b) annealed at $550^{\circ} \mathrm{C}$ and (c) annealed at $600^{\circ} \mathrm{C}$

\section{Conclusion}


In this study, $\mathrm{LiFePO}_{4}$ was synthesized by hydrothermal method, and the products was coated with carbon by the thermal decompositionof acetylene gas. The influence of carbon coating process to $\mathrm{LiFePO}_{4}$ was examined. The obtained $\mathrm{LiFePO}_{4}$ samples was crystaline phase and lattice parameter was $a=10.336 \AA, b=6.002 \AA, c=4.695 \AA$. Heating process was influenced to the microstructure and the crystallinity. Below $600^{\circ} \mathrm{C}$, amorphous phase or amorphous layer on particle surface was crystalized. Above $600^{\circ} \mathrm{C}$, the grain growth was occured, and it led to crystalline improvement. Carbon coating temperature settled at $500-600^{\circ} \mathrm{C}$ because of fine particle and good crystalinity. TG-DTA curves of the $\mathrm{LiFePO}_{4} / \mathrm{C}$ products showed weight loss above $500^{\circ} \mathrm{C}$, and it thought to be associated with carbon layer composition.

\section{References}

1. A. K. Padhi, K. S. Nanjundaswamy and J. B. Goodenough, J. Electrochem. Soc., 144, 1609 (1997)

2. C. Delmas, M. Maccario, L. Croguennec, F. Le Cras and F. Weil, Nature materials, 71, 665 (2008)

3. D. Morgan, A. Van der Ven and G. Ceder, Electrochem. and Solid-State Lett., 7(2) A30-A32 (2004)
4. S. -Y. Chung, J. T. Blocking and Y. -M. Chiang, Nature Mater., 2, 123 (2002)

5. H. Deng et al. , Journal of Power Sources, 220, $342-$ 347 (2012)

6. A. Yamada, S. C. Chung and K. Hinokuma, J. Electrochem. Soc., 148, A224 (2001)

7. J. Ni, M. Morishita, Y. Kawabe, M. Watada, N. Takeshi and T. Sakai, Journal of Power Sources, 195, 2877-2882 (2010)

8. Y. Xu, Y. Lu, L. Yan, Z. Tamg and R. Yang, J. Power Sources, 160, 570 (2006)

9. Z. Zhang, H. Feng, X. Wu, L. Wang, A. Zhang, T. Xia, H. Dong and M. Liu, Electrochim. Acta, 54, 3206 (2009)

10. M. Konarova and J. Taniguchi, J. Power Sources, 195, 3661 (2010)

11. B. Kang and G. Ceder, Nature, 458, 190 (2009)

12. K. Zaghib, A. Mauger, F. Gendron and C. M. Julien, Chem. Mater., 20, 462 (2008)

13. I. Belharouak, C. Johnson and K. Amine, Electrochem. Commun., 7, 983 (2005)

14. O. Xiuqin, P. Lin, G. Haichen, W. Yichen and L. Jianwei, J. Mater. Chem., 22, 9064 (2012) 